03,04

\title{
Влияние твердофазной рекристаллизации с двойной имплантацией на плотность структурных дефектов в ультратонких слоях кремния на сапфире
}

\author{
(C) С.Д. Федотов ${ }^{1,3}$, В.Н. Стаценко ${ }^{1}$, Н.Н. Егоров ${ }^{2}$, С.А. Голубков ${ }^{2}$ \\ ${ }^{1} \mathrm{AO}$ „Эпиэл“, \\ Зеленоград, Россия \\ 2 ЗАО „Научно-исследовательский институт материаловедения“, \\ Зеленоград, Россия \\ ${ }^{3}$ Национальный исследовательский университет „МИЭТ“, \\ Зеленоград, Россия \\ E-mail: fedotov.s.d@yandex.ru
}

Поступила в Редакцию 16 июля 2019 г.

В окончательной редакции 16 июля 2019 г.

Принята к публикации 25 июля 2019 г.

Главной технологической проблемой при изготовлении электроники на структурах кремний на сапфире (КНС) является высокая плотность дефектов в слоях кремния на сапфире. Современный метод получения ультратонких структур КНС с помощью твердофазной эпитаксиальной рекристаллизации и пирогенного утонения позволяет значительно снизить дефектность в данных слоях. Тем не менее, влияние дефектности субмикронных слоев КНС на структурное совершенство ультратонких слоев остается не ясным. В данной работе ультратонкие $(100 \mathrm{~nm})$ структуры КНС были получены на субмикронных $(300 \mathrm{~nm})$ структурах КНС, обладающих различным структурным качеством. Кристалличность слоев $300 \mathrm{~nm}$ до процесса рекристаллизации и ультратонких слоев определялось с помощью рентгеноструктурного анализа и просвечивающей электронной микроскопии. Установлено, что наименьшие значения ширины кривой качания (ШКК) 0.19-0.20 совершенных слоев КНС $300 \mathrm{~nm}$. Показано, что более совершенный приповерхностный слой базовой структуры КНС $300 \mathrm{~nm}$ и режим двойной имплантации, позволяет на порядок уменьшить плотность структурных дефектов в ультратонком слое $\mathrm{Si}$ до $\sim 1 \cdot 10^{4} \mathrm{~cm}^{-1}$.

Ключевые слова: кремний на сапфире, эпитаксия, гетероэпитаксия, газофазная эпитаксия, кремний на диэлектрике, твердофазная рекристаллизация, ультратонкий кремний, имплантация.

DOI: $10.21883 /$ FTT.2019.12.48551.57ks

\section{1. Введение}

Гетероэпитаксиальные структуры кремний-на-сапфире (КНС) известны уже более 50 лет, однако до сих пор остаются востребованными среди семейства технологий кремний на изоляторе. Интегральные схемы на структурах КНС отличаются малыми потерями мощности, повышенным быстродействием, малым энергопотреблением и более высокой собственной частотой по сравнению с аналогами на объемном кремнии. Сегодня структуры КНС в основном применяются как основа радиационно-стойких и высокочастотных микросхем, предназначенных для атомной отрасли, космического и гражданского применений. Основным технологическим барьером на пути повсеместного использования данных структур является высокая плотность дефектов в гетероэпитаксиальном слое (ГЭС) кремния. Существует несколько технологий роста малодефектных слоев КНС с помощью метода твердофазной эпитаксиальной рекристаллизации (ТЭР). Общий принцип данного метода заключается в первоначальной аморфизации субмикронного $(0.2-0.6 \mu \mathrm{m})$ слоя кремния с помощью ионной имплантации кремния [1] или кислорода [2,3], после чего для проведения твердофазной рекристаллизации используют термический $[1,2,4]$ или лазерный отжиг [5]. Далее различными способами утонения получают ультратонкие слои КНС толщиной $\leq 100 \mathrm{~nm}$ с низкой плотностью структурных дефектов. Высокое структурное совершенство КНС, полученное в результате ТЭР, приводит к повышению радиационной стойкости, снижению токов утечки и увеличению подвижности электронов в каналах МОП транзисторов на КНС [6].

Несмотря на большое количество исследований в данной области, условия и технические параметры каждого процесса ТЭР строго конфиденциальны, что не позволяет произвести адекватный анализ опубликованных данных или воспроизвести результаты сторонних исследователей полученные ранее. Также до сих пор остается открытым вопрос влияния структурного качества исходных субмикронных слоев КНС на дефектность ультратонких слоев.

Цель данной работы заключалась в исследовании влияния ТЭР с двойной имплантацией на плотность дефектов в ультратонких слоях КНС, полученных на 
субмикронных гетероструктурах КНС различного структурного качества.

\section{2. Эксперимент и методы исследования}

Наращивание субмикронных слоев КНС толщиной $300 \pm 8 \mathrm{~nm}$ производилось на подложках сапфира $\mathrm{R}$-среза диаметром $150 \mathrm{~mm}$ методом газофазной эпитаксии (ГФЭ) при атмосферном давлении. Процессы роста проведены на промышленном реакторе PE2061S (LPE, Италия) на эпитаксиальном участке АО „Эпиэл“. Стандартный технологический процесс газофазной эпитаксии КНС включал отжиг сапфира при $1000-1300^{\circ} \mathrm{C}$ в потоке водорода в течение $0.5-1 \mathrm{~h}$ и осаждение слоя КНС при $900-1000^{\circ} \mathrm{C}$ из парогазовой смеси моносилан-водород при соотношении $\mathrm{SiH}_{4}: \mathrm{H}_{2}=0.005-0.05: 1$. С целью получения субмикронных слоев КНС улучшенного структурного качества был применен модернизированный технологический режим, включающий низкотемпературную стадию формирования начального слоя кремния, наращивание основного объема слоя из смеси $\mathrm{SiH}_{4}-\mathrm{SiCl}_{4}-\mathrm{H}_{2}$ и серию термообработок ГЭС, подробно описанный в работах $[7,8]$.

Ультратонкие слои КНС толщиной $100 \pm 5 \mathrm{~nm}$ были получены методом твердофазной эпитаксиальной рекристаллизации, включающем имплантацию ионов $\mathrm{Si}^{+}$ и термический отжиг. Имплантация $\mathrm{Si}^{+}$производилась при $+22.5^{\circ} \mathrm{C}$ на модифицированной установке „Сканибалл“ (Германия) в научно-производственной лаборато-

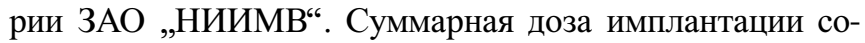
ставила $6 \cdot 10^{14}-2 \cdot 10^{15} \mathrm{~cm}^{-2}$ при энергии имплантации $135-155 \mathrm{keV}$ и плотности тока не более $1 \mu \mathrm{A} / \mathrm{cm}^{2}$. Остаточное давление в системе не превышало $2 \cdot 10^{-4} \mathrm{~Pa}$. Режим двойной имплантации заключался в последовательном сканировании всей поверхности ГЭС пучком $\mathrm{Si}^{+}$ при энергии $155 \mathrm{keV}$, затем при энергии $135 \mathrm{keV}$, общая доза имплантации оставалась на указанном уровне. Отвод тепла от гетероструктур во время имплантации производился с помощью пропускания жидкого азота через цилиндрическую камеру подложкодержателя-мишени, внутренней поверхностью которой являлась обратная сторона сапфировой подложки. После имплантации и аморфизации части субмикронного слоя $\mathrm{Si}$ производился отжиг гетероструктур при $550-1000^{\circ} \mathrm{C}$ в атмосфере азота. В результате отжига происходило устранение радиационных дефектов, протекал твердофазный переход аморфной части $\mathrm{Si}$ в монокристаллическую фазу $\mathrm{Si}(100)$ путем затравления от матрицы приповерхностного монокристаллического слоя КНС.

Структурное совершенство эпитаксиальных слоев КНС, формируемых методом ГФЭ и после проведения ТЭР, определялось с помощью метода рентгеновской дифракции и методики измерения ширины кривой качания на полувысоте максимума (ШКК, англ.: FWHM). Использовалась многофункциональная аналитическая рент- геновская система „РИКОР-X-Ray MiniLab“ (OOO „Институт рентгеновской оптики“, Москва). Средняя квадратическая погрешность определения угловых положений дифракционных пиков составила не более $0.01^{\circ}$. Средняя относительная погрешность измерения интенсивности не превышала 3\%. Измерение кривых качания проводилось для симметричного дифракционного отражения $\operatorname{Si}(400)$.

Методом просвечивающей электронной микроскопии (ПЭМ) исследовалась дефектная структура ГЭС, плотность микродвойников оценивалась количественно методом секущей по снимкам в режиме темного поля [9]. Стандартными методами были приготовлены поперечные срезы с помощью фокусированного ионного пучка на установке HELIOS (FEI, США). Исследование образцов проводилось на просвечивающем/растровом электронном микроскопе TITAN 80-300 (FEI, CША), оборудованным корректором сферической аберрации зонда. Ускоряющее напряжение при исследованиях составляло $300 \mathrm{kV}$. Исследование структуры поверхностной области слоя и межфазной границы КНС производилось методом электронографии при работе микроскопа в режиме электронографа. Ускоряющее напряжение составило около $50 \mathrm{keV}$, для получения дифракционных картин была использована схема измерения „на отражение“.

\section{3. Результаты}

Методом ГФЭ получены экспериментальные образцы гетероструктур КНС диаметром $150 \mathrm{~mm}$ с толщиной ГЭС $300 \pm 8 \mathrm{~nm}$. Все образцы были разделены на три группы в зависимости от условий технологического режима эпитаксии: U-1 - стандартный одностадийный режим ГФЭ при температуре роста $950 \pm 10^{\circ} \mathrm{C}$; U-2 стандартный одностадийный режим ГФЭ при температуре роста $950 \pm 10^{\circ} \mathrm{C}$ и отжиг гетероструктур при $940 \pm 10^{\circ} \mathrm{C} ; \mathrm{U}-3$ - модифицированный режим ГФЭ: температура роста начальной стадии составила $930 \pm 10^{\circ} \mathrm{C}$, произведен отжиг начального слоя при той же температуре, далее основной объем ГЭС сформирован при $970 \pm 10^{\circ} \mathrm{C}$ и отожжен при температуре менее $900^{\circ} \mathrm{C}$. Образцы из групп U-1 и U-2 подвергнуты ТЭР с имплантацией при $155 \mathrm{keV}$, для группы U-3 применен двойной режим имплантации $155+135 \mathrm{keV}$. Последующие пирогенное окисление и травление в концентрированной $\mathrm{HF}$ позволили получить ультратонкие структуры КНС с толщиной ГЭС $100 \pm 5 \mathrm{~nm}$.

\section{1. Рентгеноструктурный анализ}

Исследование кристалличности слоев КНС из группы U-1 показало, что процесс ТЭР улучшает структурное совершенство решетки $\mathrm{Si}$ даже в случае использования стандартных структур КНС. Величина ШКК субмикронных структур КНС была на уровне $0.45-0.48^{\circ}$, после процесса ТЭР и утонения до $100 \pm 5 \mathrm{~nm}$ ШКК 

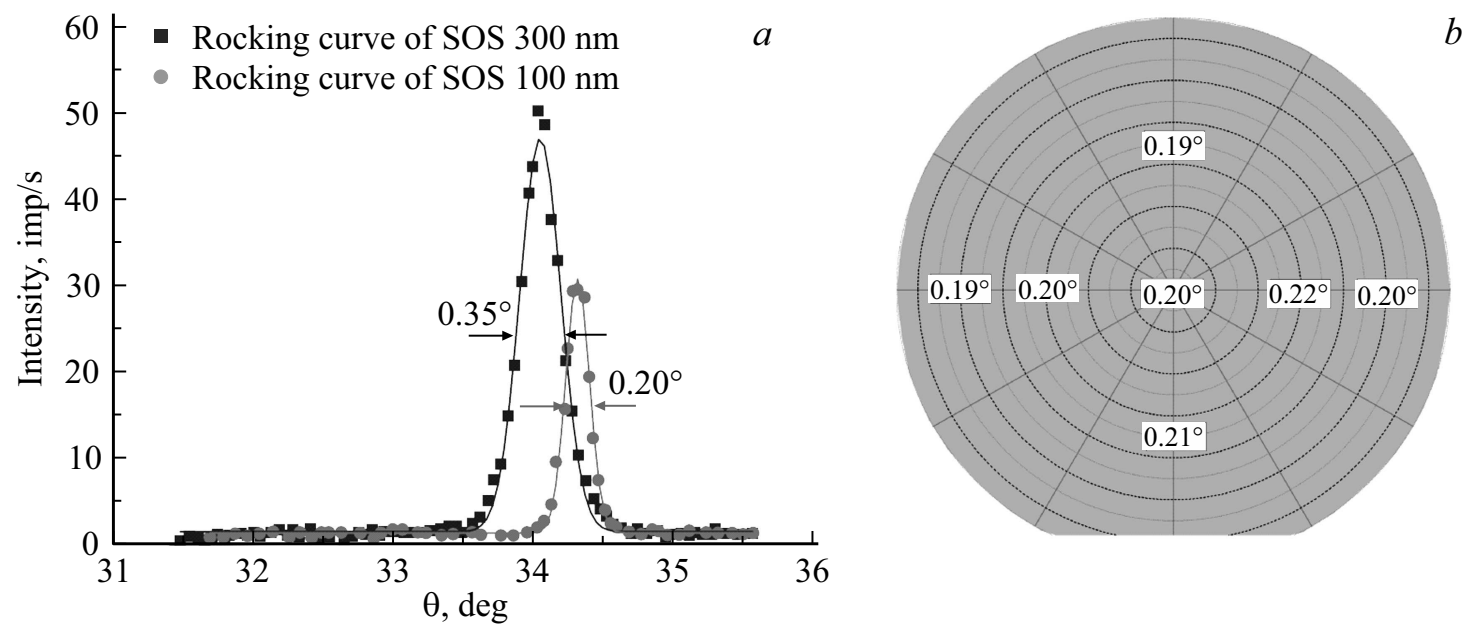

$b$

Рис. 1. Кривые качания $(\theta-2 \theta$ геометрия) для КНС различной толщины $(a)$ и карта распределения ШКК по площади $(b)$ для Ø $150 \mathrm{~mm}$, образец группы U-3.

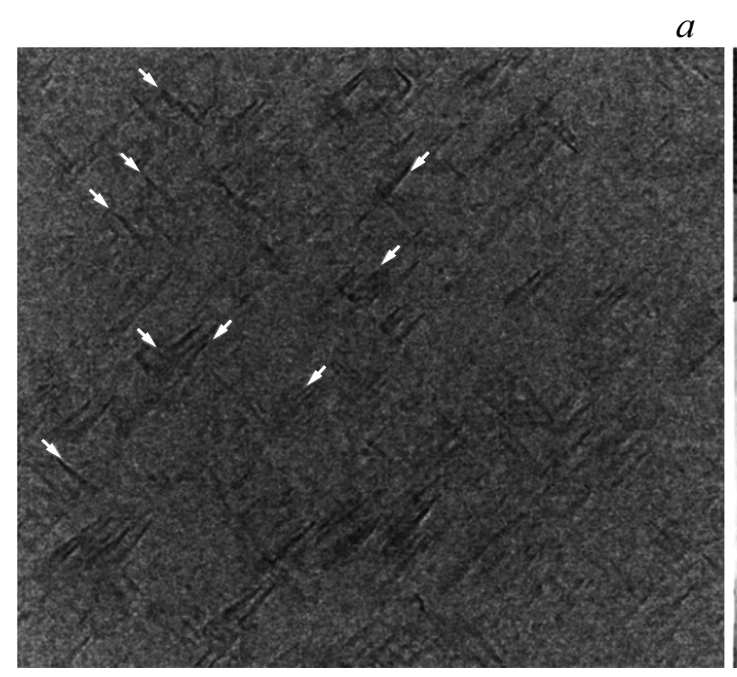

$500 \mathrm{~nm}$

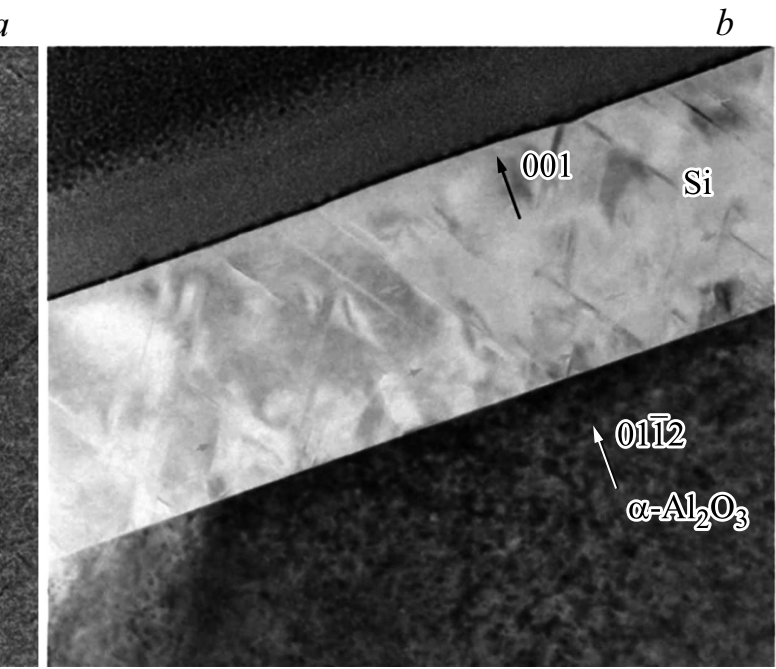

$-50 \mathrm{~nm}$

Рис. 2. Светлопольное ПЭМ изображения поверхности КНС $100 \mathrm{~nm}(a)$ и поперечного среза КНС $300 \mathrm{~nm}(b)$ группы U-1, где светлыми стрелками показаны микродвойники в плоскостях $(\overline{1} 1 \overline{1})$ и $(\overline{1} 11)$, черной стрелкой показана неровность на поверхности.

уменьшилась до $0.32-0,33^{\circ}$. В случае образцов группы U-2 величина ШКК субмикронных слоев КНС до ТЭР составила $0.38-0.40^{\circ}$, после рекристаллизации ШКК слоев КНС $100 \pm 5 \mathrm{~nm}$ составила $0.25-0.27^{\circ}$. Для образцов из группы U-3 слои КНС $300 \pm 8 \mathrm{~nm}$ характеризовались улучшенной кристалличностью и величиной ШКК $0.35-0.36^{\circ}$, после проведения двойной имплантации и ТЭР с утонением ШКК была снижена до 0.19-0.20. На рис. 1 продемонстрированы результаты рентгеноструктурного анализа образца из группы U-3.

Установлено, что отжиг гетероструктур in situ после ГФЭ приводит к снижению ШКК субмикронных структур КНС, что позволяет получить наименьшее значение данного параметра для ультратонких слоев КНС при одном и том же режиме имплантации. Использование модифицированного технологического режима ГФЭ и режима двойной имплантации $155+135 \mathrm{keV}$ позволяет получить ультратонкие слои КНС наилучшего структурного качества. Полученные карты распределения демонстрируют связь разброса ШКК кремния на сапфире до и после процесса ТЭР, значение ШКК пропорционально изменяется для различных участков на площади структур КНС.

\section{2. Просвечивающая электронная микроскопия}

В первую очередь изучены образцы субмикронных слоев КНС $300 \pm 8 \mathrm{~nm}$ и ультратонких слоев $100 \pm 5 \mathrm{~nm}$ из группы U-1, полученные без использования процесса ТЭР. Изображения поверхности и среза данных структур в режиме светлого поля показаны на рис. 2. 


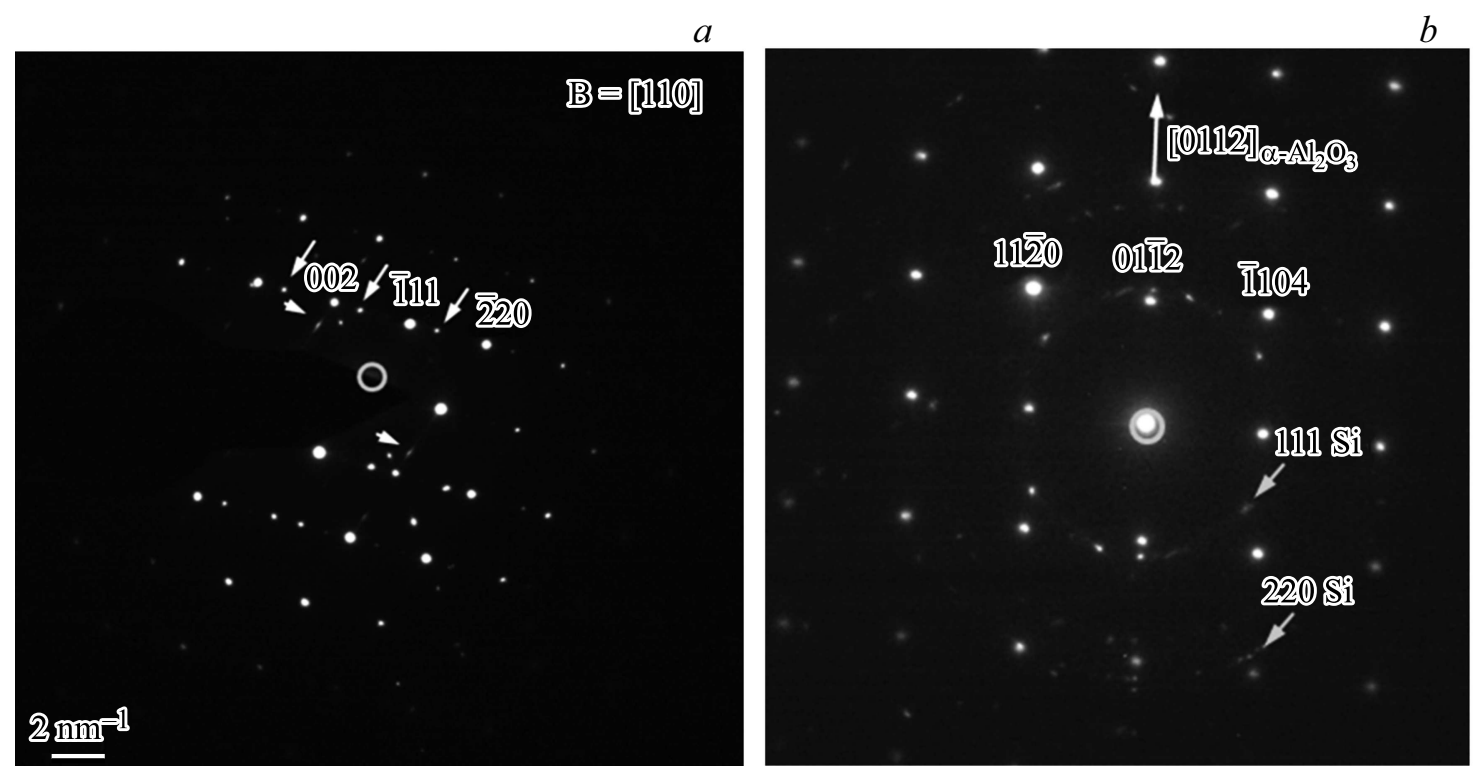

Рис. 3. Электронограммы от кремния с осью зоны $B=[110]$ КНС $300 \mathrm{~nm}(a)$ и межфазной границы $\mathrm{Si}_{-} \mathrm{Al}_{2} \mathrm{O}_{3} \mathrm{KHC} 100 \mathrm{~nm}(b)$, стрелками показаны рефлексы от двойников.

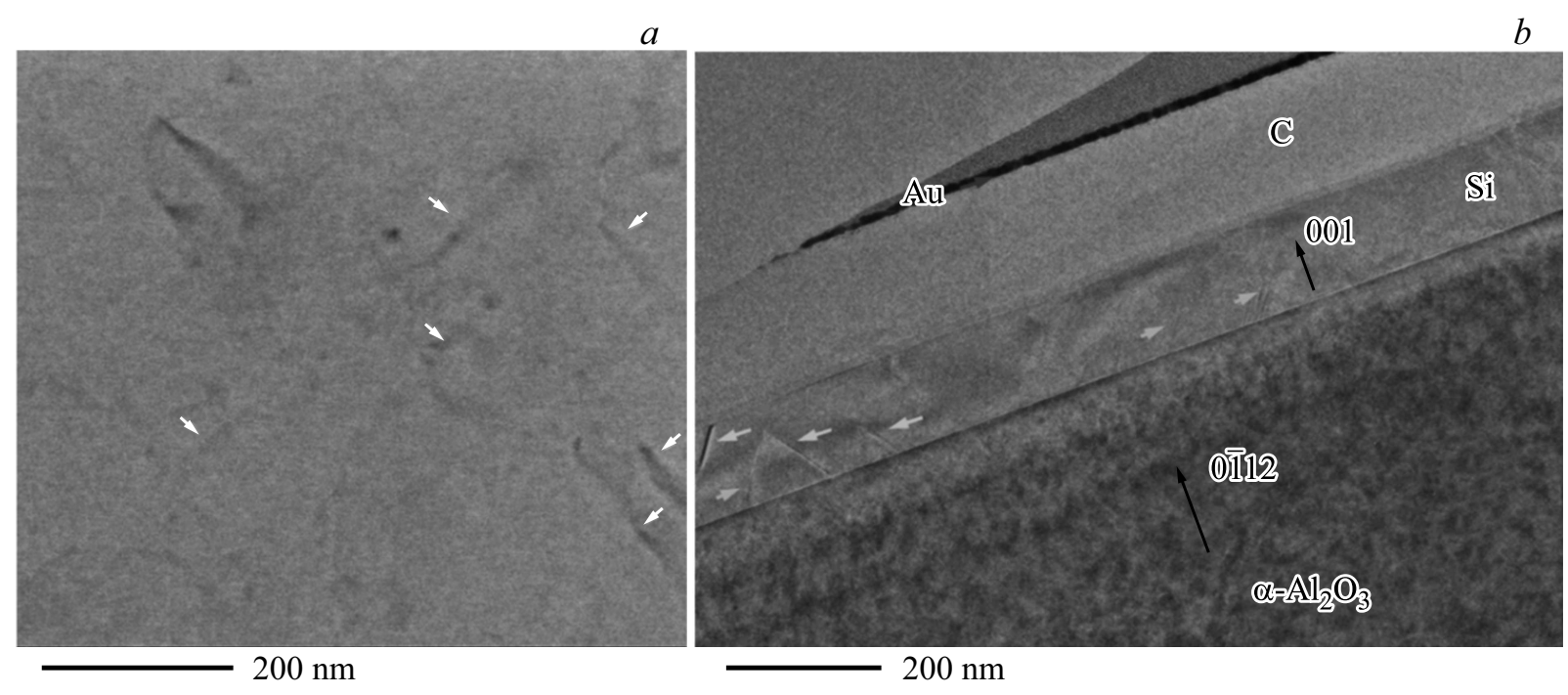

Рис. 4. Светлопольные изображения поверхности $(a)$ и поперечного среза $(b)$ образца КНС 100 nm группы U-2.

На поверхности КНС $100 \mathrm{~nm}$ четко различаются выходы двойников. В объеме ГЭС КНС $300 \mathrm{~nm}$ видны двойники, расположенные параллельно плоскости $\{111\}$ (желтые и зеленые стрелки). Плотность микродвойников максимальна вблизи межфазной границы и постепенно уменьшается к поверхности слоя за счет аннигиляции микродвойников.

Микродвойники наблюдаются по всей толщине субмикронного слоя КНС, начиная от границы раздела и заканчивая приповерхностным слоем $\mathrm{Si}$. Кроме двойников в ГЭС обнаружены дислокации, большая часть которых представляет собой двойникующие дислокации, берущие свое начало в ступеньках на границе двойникования. Остальные представляют собой, предположительно, ча- стичные $30^{\circ}$ дислокации Шокли. Установлено, что при пересечении двойников с разными плоскостями двойникования происходит их аннигиляция - прекращение роста одного из них и переход другого в двойникующую дислокацию. Таким образом, обеспечивается частичное снижение плотности микродвойников с увеличением толщины слоя.

На рис. 3 показаны электронограммы, полученные отдельно от кремния $B=[110]_{\mathrm{Si}}$ КНС $300 \mathrm{~nm}(a)$ и от межфазной границы $\mathrm{Si}-\mathrm{Al}_{2} \mathrm{O}_{3} \mathrm{KHC} 100 \mathrm{~nm}(b)$ образцов группы U-1. На рис. 2, $a$ стрелками обозначены рефлексы от микродвойников с границами двойникования параллельно $(\overline{1} 1 \overline{1})$ и (1ㅣ). Рефлексы от электронов образуют кольцевой паттерн (рис. $3, b)$, что говорит о 


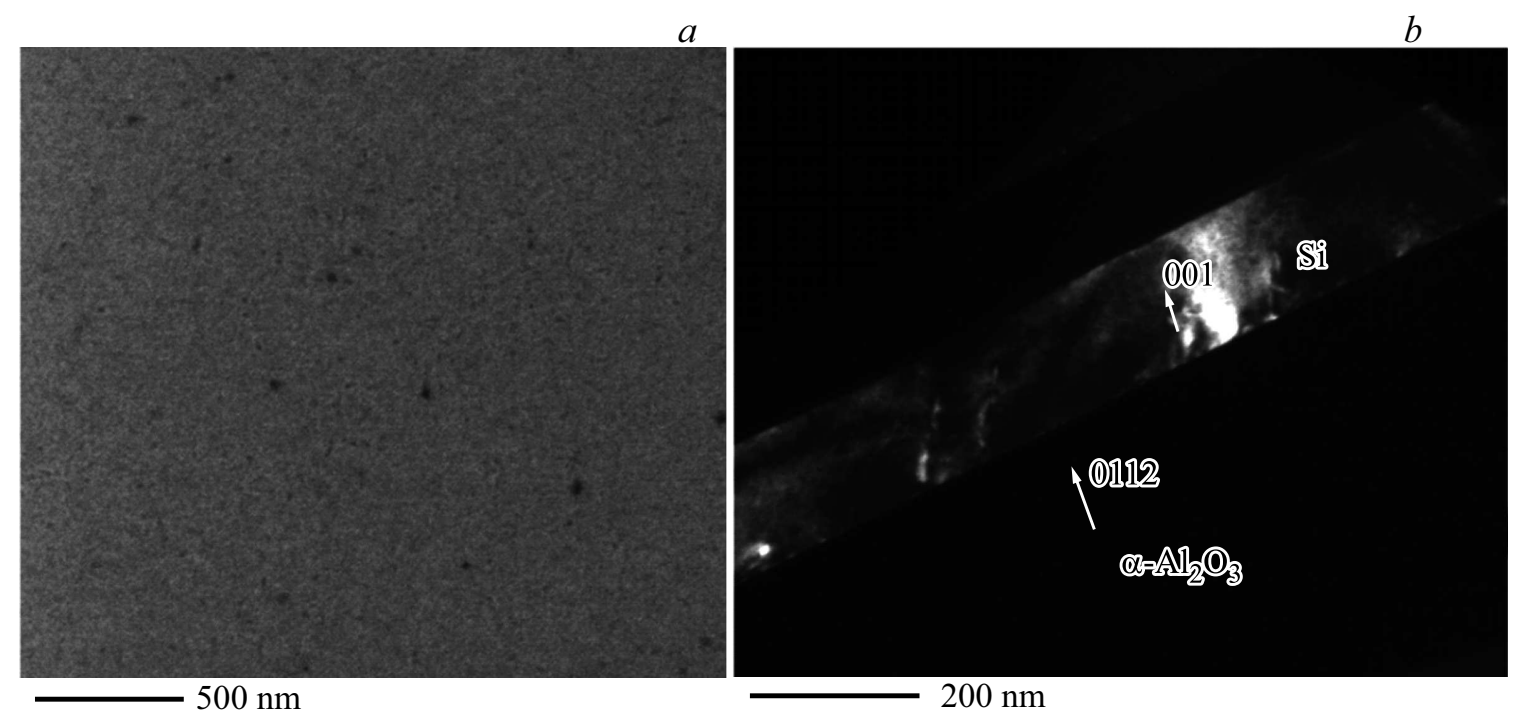

Рис. 5. Светлопольное ПЭМ-изображения поверхности $(a)$ и темнопольное среза $(b)$ КНС 100 nm группы U-3.
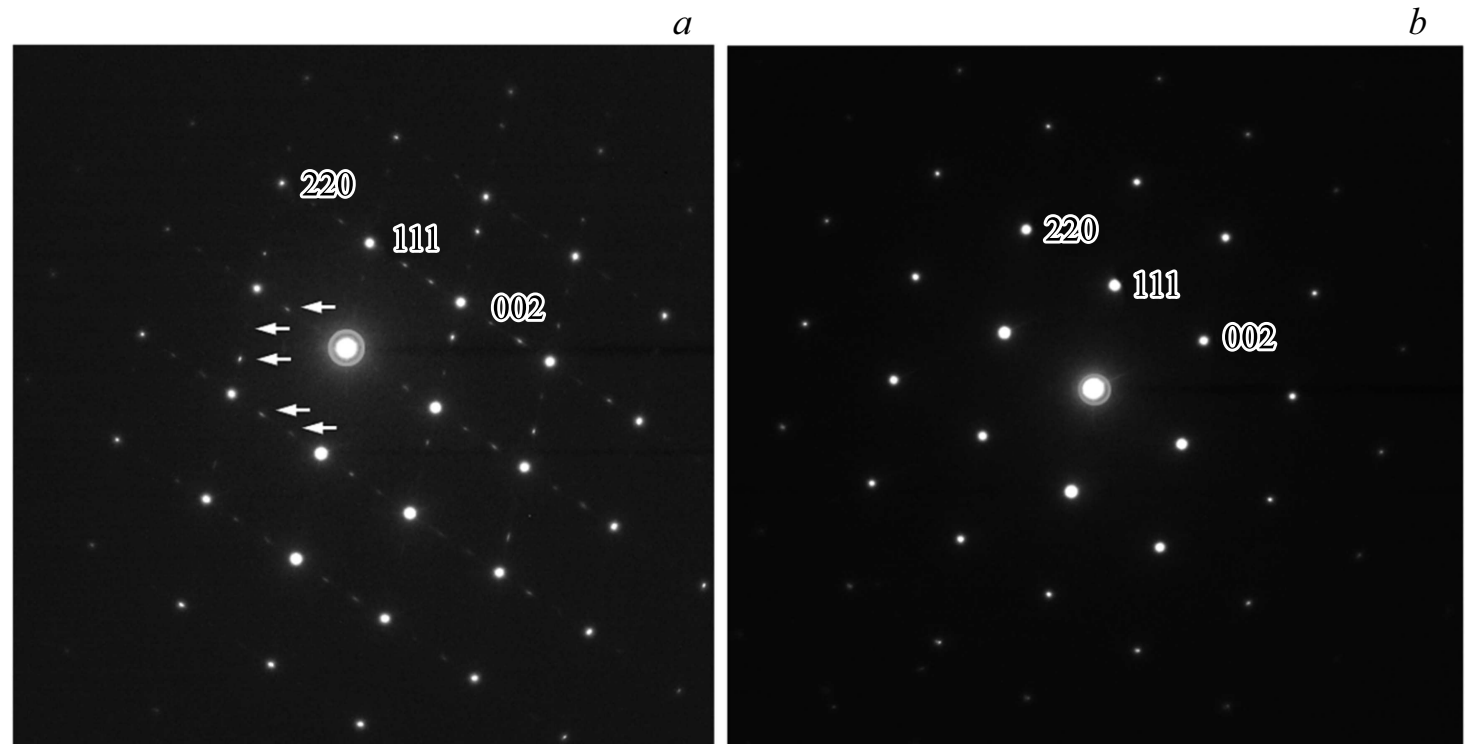

Рис. 6. Электронограммы, полученные от кремния $B=[110]_{\mathrm{Si}}$ для КНC $100 \mathrm{~nm}$ группы U-2 (a) и группы U-3 (b), стрелками показаны рефлексы от двойников.

высокой разориентации кристаллических зерен и возможной поликристаллической структуре кремния вблизи межфазной границы. Сравнительно интенсивные рефлексы наблюдаются от ориентационных соотношений $[01 \overline{1} 2]_{\alpha-\mathrm{Al}_{2} \mathrm{O}_{3}} \|[001]_{\mathrm{Si}}$ и $[01 \overline{1} 2]_{\alpha-\mathrm{Al}_{2} \mathrm{O}_{3}} \|[111]_{\mathrm{Si}}$, что говорит о наличии кристаллических зерен ориентацией $\operatorname{Si}(100)$ и (111) примерно в равном соотношении на начальном этапе зародышеобразования. Стоит отметить, что включения зерен $\mathrm{Si}(111)$ наблюдались и для КНС $300 \mathrm{~nm}$, однако для данной толщины они были уже покрыты матричной кристаллической фазой $\mathrm{Si}(100)$, обладающей более высокой скоростью роста.

Светлопольные изображения поверхности и среза ультратонких слоев КНС группы U-2 представлены на рис. 4. Стрелками показаны микродвойники с границами двойникования параллельно (1ㅣㄹ), зелеными стрелками - (11). На поверхности слоя наблюдаются выходы двойниковых дислокаций, что также было замечено на поверхности образцов КНС из группы U-1, однако в значительно меньшем количестве. В режиме светлого поля на срезах четко видны микродвойники параллельные плоскости $\{111\}$. Вероятно, оставшиеся микродвойники являются результатом неудачной рекристаллизации от дефектной приповерхностной части слоя КНС.

Проводя сравнение КНС 100 nm из групп U-1 и U-2, можно установить, что процесс ТЭР позволяет значительно уменьшить плотность структурных дефектов в объеме слоя. Наблюдаемые остаточные дефекты скорее 
Расчет плотности структурных дефектов КНС $100 \mathrm{~nm}$

\begin{tabular}{c|c|c}
\hline Группа & Толщина Si,nm & $\begin{array}{c}\text { Плотность двойников } \\
\text { и дислокаций Шокли, } \mathrm{cm}^{-1}\end{array}$ \\
\hline I & $100 \pm 5$ & $6 \cdot 10^{5}$ \\
II & $105 \pm 5$ & $3 \cdot 10^{5}$ \\
III & $105 \pm 5$ & $1 \cdot 10^{4}$
\end{tabular}

всего являются реконструированными двойникующими дислокациями, прорастающими из дефектной матрицы приповерхностной части слоя субмикронной структуры КНС. Кроме того, возможно обратное прорастание кристаллических зерен некогерентных с матрицей ориентаций в процессе рекристаллизации $\mathrm{Si}$. На сегодняшний день в открытой литературе нет данных, касающихся взаимосвязи скорости прохождения фронта кристаллизации и ориентации $\mathrm{Si}$ в объеме подобных гетероструктур.

На рис. 5 показаны светлопольное изображение поверхности $(a)$ и темнопольный снимок среза $(b)$ образцов КНС $100 \mathrm{~nm}$ из группы U-3. На поверхности ультратонкого слоя $\mathrm{Si}$ выходы двойникующих дислокаций не были обнаружены (рис. 5,a). Темнопольное изображение среза (рис. $5, b$ ) данной структуры демонстрирует отсутствие микродвойников, которые были бы видны как четкие светлые контрастные линии. Очевидно, что более совершенный приповерхностный слой субмикронной структуры, от которого происходит зарождение и рекристаллизация, позволяет сформировать структурно совершенный слой ультратонкого кремния.

На рис. 6 показаны электронограммы, полученные от кремния $B=[110]_{\mathrm{Si}}$ для КНС $100 \mathrm{~nm}$ группы U-2 (a) и группы U-3 $(b)$. Стрелками обозначены характерные рефлексы от микродвойников, проявляющиеся на электронограмме ультратонкого слоя КНС из группы U-2. Электронограмма УТК из группы U-3 демонстрирует отсутствие рефлексов от двойниковых ламелей, а также высокую интенсивность отражений, характерных для матричной ориентации $\mathrm{Si}(100)$, что говорит о высоком структурном качестве данного образца.

В таблице приведены результаты расчета линейной плотности двойников и дислокаций в слоях КНС 100 nm экспериментальных групп КНС, полученные методом секущей по снимкам в режиме темного поля.

\section{4. Заключение}

Рентгеноструктурный анализ субмикронных и ультратонких слоев КНС показал, что наименьшие значения ШКК 0.19-0.20 из группы U-3. Установлено, что структурное совершенство ультратонких слоев КНС зависит от ШКК субмикронных слоев. Использование субмикронных гетероструктур, изготовленных по модифицированному режиму ГФЭ (U-3) позволяет уменьшить величину ШКК ультратонких слоев КНС после рекристаллизации на $\sim 37 \%$ в сравнении со стандартными структурами (U-1). Методом ПЭМ обнаружен эффект прорастания дефектов и кристаллических зерен некогерентных ориентаций от структурных нарушений матрицы приповерхностного затравочного слоя в процессе ТЭР. Показано, что более совершенный приповерхностный слой базовой структуры КНС $300 \mathrm{~nm}$, позволяет на порядок уменьшить плотность структурных дефектов в ультратонком слое $\mathrm{Si}$ до $\sim 1 \cdot 10^{4} \mathrm{~cm}^{-1}$.

\section{Конфликт интересов}

Авторы заявляют, что у них нет конфликта интересов.

\section{Список литературы}

[1] Q.-Y. Wang, J.P. Nie, F. Yu, Z.L. Liu, Y.H. Yu. Mater. Sci. Eng. B 72, 189 (2000).

[2] Q.-Y. Wang, Yu. Zan, J. Wang, Y.-H. Yu. Mater. Sci. Eng. B 29, 43 (1995).

[3] А.А. Чистилин, А.А. Романов, Ю.М. Московская, А.В. Уланова. Микроэлектроника 40, 224 (2011).

[4] П.А. Александров, К.Д. Демаков, С.Г. Шемардов, Ю.Ю. Кузнецов. ФТП 43, 626 (2009).

[5] P. Baeri, E. Rimini. Mater. Chem. Phys. 46, 169 (1996).

[6] K. Tsui, K.J. Chen, S. Lam, M. Chan. JJAP 42, 4982 (2003).

[7] S.D. Fedotov, E.M. Sokolov, V.N. Statsenko, A.V. Emelyanov, S.P. Timoshenkov. Semiconductors 51, 1692 (2017).

[8] С.Д. Федотов, Е.М. Соколов, В.Н. Стаценко, А.В. Ромашкин, С.П. Тимошенков. Изв. вузов. Электроника 23, 454 (2018).

[9] Д. Синдо, Т. Иокава. Аналитическая просвечивающая электронная микроскопия. Техносфера, М. (2006). 256 с.

Редактор К.В. Емцев 